\title{
International Competitiveness of the Food Industry in European Union Member States
}

\author{
Malgorzata Juchniewicz \\ $\mathrm{PhD}$, professor of the University of Warmia and Mazury in Olsztyn (UWM) \\ Katarzyna Łukiewska \\ MSc, University of Warmia and Mazury in Olsztyn, Department of Business Economics \\ kep@uwm.edu.pl
}

\begin{abstract}
The primary purpose of the study was to assess the international competitiveness of the food industry in EU member states in trade to the world market and its changes in the years 2005-2012. The food industry was defined on the basis of the aggregation of departments at the two-digit level 01-09 and 11 of the Standard International Trade Classification SITC Rev. 3. The study uses the following indexes based on foreign trade. The share of export in the global market, the revealed comparative advantage index RCA, in index of import coverage with export and index the Grubel-Lloyd index of intraindustry trade were calculated. Due to the numerous aspects of the competitiveness phenomenon, the aggregate variable was also used for a complex assessment. A synthetic measure of international competitiveness was developed on the basis of the factors referred to above. Data published in the UN Comtrade database was used for the calculations. The conducted research indicates that the international competitive position of the food industry of particular EU member states was diverse. The highest places in the competitiveness ranking were occupied by states of the old EU, such as: the Netherlands, France, Spain and Denmark. Only their order changed, depending on the adopted time criterion. A particular improvement was observed among Central-Eastern European countries which belong to new member states. However, it mainly resulted from the low level of export in the initial period. On this basis, we may state that we should not expect significant changes in the level of international competitiveness of the food industry in particular EU member states in the future (maintaining the present conditions).
\end{abstract}

Keywords: competitiveness, food industry, international trade

\section{Introduction}

Competition is one of the basic economic mechanisms of the market economy. Competing with other entities, understood as rivalry to achieve benefits related to functioning on the domestic and international markets (Misala 2007) is an indispensable element of the activity of each entity. Despite the fact that research on competitiveness has been going on for more than 40 years 1 and the notion competitiveness is currently commonly used both in the theory and in practice of economics, competitiveness still remains a notion which is not clearly defined. The difficulty in defining competitiveness is related to the fact that this is an issue with numerous aspects and dimensions. Competitiveness originates from three economic theories: the theory of economic growth, international trade and microeconomics (Wziatek-Kubiak 2003) and it may be referred to various aggregation levels: domestic economies, industries, regions and companies (Frohberg, Hartman 1997). The Organization for Economic Co-operation and Development defines competitiveness as: "the ability of companies, industries, regions, nations or supranational regions to generate, Chile being and remaining exposed to international competition, relatively high factor income and factor employment levels on a sustainable basis" (Hatzichronoglou, 1996, p. 20). The European Commission defines competitiveness as: "the ability of an economy to provide its population with high and rising standards of living and a high level of employment for all those willing to work on a sustainable basis" (European Comeptitiveness... 2003, p. 19). Regarding the research on sectors of the domestic economy, competitiveness is usually related to the international market and is assessed. Numerous authors accept the competitiveness of industries as: "the ability to profitably gain and maintain market share in domestic and/or foreign markets" (Martin et al., 1991, p. 1456, Pitts and Lagnevik 1997, Fisher and Schornberg, 2007, p. 475). Another definition defines the international competitiveness of a sector as "sustained ability of nation's industry or firms to compete with foreign counterparts in foreign markets as well as in domestic markets under conditions of free trade (Kim and Marion 1995, p. 5). In such understanding, competitiveness is a zero-sum game since the growth in the competitiveness of the

1 The notion competitiveness appeared for the first time in the economic literature in the 1970s. The first attempts to define and determine the degree of the international competitiveness of competing countries were undertaken in a study by the US Department of Labor regarding the commercial expansion and increased export of Japanese companies to the US market (Pawlak 2013). 
industry of one country is related to the decrease in the competitiveness of others. Regarding the food industry, competitiveness is defined as: "the ability to constantly strengthen and maintain a profitable share in domestic and export markets on which the industry is active" (Wijnands et al., 2006, p. 18).

The topic of competitiveness of the food industry is particularly significant due to the importance of this industry in the economy of the entire European Union and particular member states. The food industry is one of the most important and the most dynamically developing sectors of the European economy. It consists of approx. 287,000 companies. The food industry is the second largest sector of industrial production in terms of added value (after the metal industry). Added value of this industry is $12.5 \%$ of added value generated by the production sector and $1.8 \%$ of the GDP. The food industry is also the main employer in the EU. Employment in this sector is more than 4.25 million people which is $15.0 \%$ of all employees in the production sector (Data\&Trends..., 2012). In addition, food is a strategic product. Therefore, the EU, but also numerous countries all over the world, aims at maintaining and improving the competitiveness of food production. The research of Wijands and others (2008) demonstrates a relatively good competitive position of the food industry in such countries as the United States, Brazil, Canada and Australia. The growth in competitiveness on international markets, especially under conditions of growing liberalization of international trade as well as developing integration and globalization, is inevitable and is at the same time a key challenge for the European food industry.

\section{Method}

\section{Materials}

The study uses statistical data relating to the value of global export and import. The source of data was the UN COMTRADE database. The food industry was defined on the basis of the aggregation of departments separated at the two-digit level according to the Standard International Trade Classification (SITC) Rev. 3: 01 Meat and meat preparations, 02 Dairy products and birds' eggs, 03 Fish (not marine mammals), crustaceans, mollusks and aquatic invertebrates, and preparations thereof, 04 Cereals and cereal preparations, 05 Vegetables and fruit, 06 Sugars, sugar preparations and honey, 07 Coffee, tea, cocoa, spices, and manufactures thereof, 08 Feeding stuff for animals (not including unmilled cereals), 09 Miscellaneous edible products and preparations, 11 Beverages. The time scope of the research covered the years 2005-2012.

\section{Procedure}

The research was conducted with the use of a set of four quantity indexes of the international competitive position selected on the basis of substantive premises as well as the availability of statistical data: export market share (EMS), revealed comparative advantege (RCA), trade coverage (TC) as well as Grubel-Lloyd index (GL). Then, a synthetic index of international competitiveness of the food industry was developed on the basis of the measures referred to above. Export market share is one of the most important and the most popular indexes of the competitive position. It presents the share of a given country in the global export of the food industry:

where:

$$
E M S=\frac{E_{F i}}{E_{F W}}
$$

$E_{F i}$ - export of food products of the country i,

$E_{F W}$ - world export of food products.

The second used index is the Revealed Comparative Advantege of Balassa (Balassa 1965). The index measures the share of the food industry in the country's total export as compared to the share of this industry in the total global export:

where:

$$
R C A=\frac{\frac{E_{F i}}{E_{i}}}{\frac{E_{F W}}{E_{w}}}
$$

$E_{i}$ - total export of the country i,

$E_{F W}$ - world export of food products,

$E_{w}$ - total world export.

The index assumes values ranging from 0 to infinity, and two intervals of various interpretations are distinguished. If

$R C A>1$, then the share of the food industry in the country's export to the global market is higher than the share of this 
industry in the total global export. This means that the examined country has revealed comparative advantages in export to this market, and thus is competitive. On the other hand, when $0<R C A<1$, then the share of the food industry in the export of a given country is lower than the share of this industry in the global export and the examined country does not revealed comparative advantages in export to the global market.

Trade Coverage refers to one of the simplest and, at the same time, basic measures of the competitive position, namely the balance of commercial turnover. Competitiveness is identified with obtaining a surplus in trade exchange. The index determines to what extent income from the export of food products cover the expenses for the import of these products:

where:

$$
T C=\frac{E_{F i}}{I_{F i}}
$$

$I_{F i}$ - import of food products of the country $\mathrm{i}$.

The TC index's value above 1 means that the country generates a surplus in the trade in food products and, as a result, has competitive advantage in the exchange of products of this group. The value of the index below 1 means a deficit in trade turnover which proves a weak competitive position on foreign markets.

The analysis of intra- and inter-industry exchange is also an important issue regarding the trade in food products. Intraindustry exchange consists in "the simultaneous export and import of products (also assemblies, subassemblies and components) coming from the same branch, being close substitutes in the sphere of consumption, production or in both of these spheres in total" (Grubel, Lloyd 1975, p. 35). The intensity of intra-industry trade was calculated with the use of the Grubel-Lloyd Index (Grubel, Lloyd 1971, p. 496):

$$
G L=1-\frac{\left|E_{F i}-I_{F i}\right|}{E_{F i}+I_{F i}}
$$

The index assumes values from the range $<0,1>$. The value 0 means that the entire exchange is of an inter-industry nature (only the export or import of food products is present). The value 1 means that the entire exchange is of an intraindustry nature (the value of export is equal to the value of import). The growth in the importance of this type of exchange is usually treated as a sign of the growth in the country's competitiveness in international trade (Sobków, Łapińska 2008, p. 384).

The numerous aspects of the international competitiveness phenomenon results in the fact that the application of only one-dimension measures for its assessment is insufficient. In order to analyze this phenomenon in a complex manner, it is necessary to apply total methods the idea of which consists in the construction of one aggregate variable. For this reason, a synthetic index of international competitiveness was developed on the basis of international competitiveness indexes referred to above. The values of partial indexes were listed in the form of matrix X:

where:

$$
X=\left[\begin{array}{ccc}
x_{11} & \cdots & x_{1 m} \\
\vdots & \ddots & \vdots \\
x_{n 1} & \cdots & x_{n m}
\end{array}\right]
$$

$x_{i j}$-value of $\mathrm{j}$ feature in the country $\mathrm{i}$,

$i=1,2 \ldots n,(n=28)$ - number of country,

$j=1,2 . ., m(m=4)$ - number of feature.

Then, their variability was standardized with the use of the standardization procedure and units in which they were expressed were removed:

$$
z_{i j}=\frac{x_{i j}-\overline{x_{j}}}{S_{j}}
$$

where:

$z_{i j}$ - value of standardized $\mathrm{j}$ feature in the country $\mathrm{i}$,

$x_{i j}$ - value of $\mathrm{j}$ feature in the country $\mathrm{i}$,

$\overline{x_{j}}$ - arithmetic mean of $\mathrm{j}$ feature,

$S_{j}$ - standard deviation of $\mathrm{j}$ feature.

Matrix $Z$ of standardized values of initial features was obtained as a result of such transformation: 


$$
Z=\left[\begin{array}{ccc}
Z_{11} & \cdots & z_{1 m} \\
\vdots & \ddots & \vdots \\
z_{n 1} & \cdots & z_{n m}
\end{array}\right]
$$

The obtained standardized variables $z_{i j}$ had a constant variance equal to 1 and an arithmetic mean equal to 0 as well as identical names and scopes of variability and could be compared as well as aggregated. A non-model method was used to develop the synthetic index of international competitiveness (IC). The method consists in averaging the standardized values of diagnostic features, namely four partial indexes of international competitiveness:

$$
I C_{i}=\frac{1}{m} \sum_{j=1}^{m} z_{i j}
$$

$I C_{i}$ - the International Competitiveness Index.

The higher the values of this index, the higher the level of the country's international competitiveness on the global market. Rankings of the competitiveness of the food industry in EU member states were created on the basis of the synthetic index.

\section{Results}

The primary purpose of the study was to assess the international competitiveness of the food industry in EU member states in trade to the world market and its changes in the years 2005-2012.

\section{Findings of Export Market Share}

Countries of the old EU had the largest significance on the global export market of food products throughout the analyzed period 2005-2012 (Table 1). Germany, the Netherlands and France unquestionably occupied the highest places among EU exporters. The share of each of these countries in the global export of food products exceeded $6 \%$. A group of countries which were significant in terms of share in the global export market also included Spain, Belgium, Italy and Great Britain in which the share in the global market in 2012 amounted to 2.64\%-3.77\%. Countries in which the share was higher than $1 \%$ also included: Denmark, Ireland, Austria as well as Poland, which is the largest food exporter among countries of the new EU. Only Poland recorded a growth in the share of export (by 0.49 percentage points) among all countries referred to above. A considerable improvement could also be noticed in other countries of Central and Eastern Europe: Romania (0.23 pp), Lithuania (0.21 pp), Hungary (0.12 pp), Bulgaria (0.11 pp), Latvia (0.11 pp), Slovakia (0.10 pp), the Czech Republic (0.09 pp), Estonia (0.04 pp) and Slovenia (0.01 pp). The growth in the export of food products in these countries was related, above all, to the accession to the EU and the liberalization of trade within the Community. However, it is worth noting that despite the growth in the value of export, the significance of these countries on the global market is still marginal - their share in the global export market did not exceed $1 \%$. The least competitive countries, due to a small share in the global market and its negative changes, include: Cyprus, Finland, Greece as well as Luxembourg.

\section{Findings of Revealed Comparative Advantage index}

In order to assess the competitiveness of the food industry of particular EU member states, it is important to identify the importance of the export of this industry not only on the global food market but also in the country's total export. The concept of revealed comparative advantage according to Ballasa assumes the comparison of the share of the food industry in the country's total export with the share of this industry in the global export (Table 2). The analysis of the RCA index indicates the fact that Latvia, Denmark, Cyprus, Lithuania, Greece and Spain demonstrated the largest comparative advantages. The significance of the food industry in the country's total export in these countries was more than twice as high as the respective share in the total global export. In the examined period Latvia and Lithuania strengthened comparative advantages in export to the global market (growth in RCA respectively by $42.20 \% ; 25.01 \%$ ), while Greece, Denmark, Spain and Cyprus reduced them (reduction in RCA respectively by $24.03 \%, 13.90 \%, 6.44 \%, 4.24 \%$ ). The following countries had smaller comparative advantages: the Netherlands, France, Croatia, Poland, Bulgaria, Ireland, Portugal, Belgium, Estonia, Italy, Hungary and Austria. Most of these countries, except for Estonia, Belgium and the Netherlands, strengthened their competitiveness in this respect. Malta was the only country which lost its comparative advantages regarding products of the food industry in the analyzed period. The RCA index in Malta decreased from the 
ISSN 2411-9563 (Print) ISSN 2312-8429 (Online)
European Journal of Social Sciences Education and Research
September-December 2014

Volume 1, Issue 2

level 1.03 in 2005 to the level 0.66 in 2012 (by 35.38\%). 8 EU member states did not obtain comparative advantages throughout the entire analyzed period. This suggests a relatively small importance of the food industry in the total export of these countries. These include: Great Britain, Romania, Germany, Malta, Slovakia, the Czech Republic, Slovenia as well as Finland. In most of these countries, except for the Czech Republic and Slovakia, a growth in the RCA index was observed. Romania definitely had the largest one (187.25\%).

\section{Findings of Trade Coverage}

The growth in the export and import of food products in all Community states was common in the analyzed period. Relations between these categories are significant in the context of the competitiveness of this industry. 11 member states obtained an advantage in the value of export over import throughout the entire analyzed period (Table 3). In 2012 Hungary recorded relatively the largest surplus in trade exchange in the Community scale, measured with the value of the TC index (1.85). Hungary's income from the export of food products exceeded the expenses on account of import almost twice. Countries which ranked on further places regarding the value of the TC index included Denmark (1.54), the Netherlands (1.46), Ireland (1.44), Poland (1.41) and Spain (1.31). Net exporters, namely competitive countries, also included France (1.28), Lithuania (1.27), Belgium (1.19), Bulgaria (1.14) as well as Latvia (1.14). In the absolute perspective, countries of the old EU obtained definitely the largest value of commercial surplus: the Netherlands (USD 21 trillion) and then France (USD 14 trillion), Spain (USD 9 trillion), Denmark (USD 6 trillion) and Belgium (USD 5.8 trillion). In the analyzed period Austria evolved from an exporter into a net importer. This resulted from a greater growth in the import of food products than export. Throughout the entire analyzed period the remaining 16 member states recorded a negative balance of foreign trade in food and were net importers. Among these countries, in 2012 income from the export of food products covered the expenses for import to the greatest extent in Italy (0.95), Germany (0.91) and Estonia (0.89). A relatively high trade deficit, measured with the value of TC, was recorded in Croatia (0.63), the Czech Republic (0.76), Finland (0.39), Greece (0.73), Luxembourg (0.46), Malta (0.35), Portugal (0.59), Slovakia (0.77), Slovenia (0.45) Sweden (0.57), Great Britain (0.49) and Romania (0.69). The least favorable situation was recorded in Cyprus where the import was almost four times larger than the export.

The largest changes in the TC index values in the analyzed period were recorded in Bulgaria (increase by 186.30\%). An almost sevenfold growth in export with the simultaneous but significantly slower growth in import of food which grew more than twice played a key role. Significant favorable changes were also recorded in Latvia (increase by $72.55 \%$, as a result of growth in export by $291.59 \%$ and growth in import by $126.94 \%$ ), Greece (increase by $43.17 \%$, as a result of growth in export by $76.46 \%$ and import by $23.25 \%$ ) and Portugal (increase by $38.19 \%$, as a result of growth in export by $112.25 \%$ and import by $53.80 \%$ ).

\section{Findings of Grubel-Lloyd Index}

The analysis of two-way trade was another one of the applied methods to assess the competitive position of a given country in the international exchange of goods. The analysis of the Grubel-Lloyd index indicates a significant share of intra-industry exchange in most Community countries (Table 4). In some countries, even more than $90 \%$ of exchange was of an intra-industry nature. This type of exchange was the dominant form of trade in food industry products in Austria, Italy, Germany, Estonia, Latvia and Belgium. It should be assumed that it was these countries which obtained the majority of benefits related to the following factors: the diversity of products offered on markets, growing benefits of the scale as well as the growth in the effectiveness of using production factors. The Czech Republic, Greece, Ireland, Lithuania, the Netherlands, Poland, Romania and Spain also conducted an intensive intra-industry exchange. Countries which were distinguished by the lowest level intensity of intra-industry exchange included Cyprus, Finland, Luxembourg, Malta as well as Great Britain. The significance of intra-industry turnover in the analyzed period increased to the greatest extent in Romania in which the Grubel-Lloyd index increased from the level 0.39 in 2005 to the level 0.82 in 2012 (increase by $110.31 \%$ ).

\section{Findings of International Competitiveness Index}

The synthetic index of international competitiveness enables a total assessment of competitiveness including various aspects of this phenomenon (Table 5). The highest competitiveness of the food industry throughout the entire analyzed period was demonstrated by the same countries, only their order changed. The first position, since 2009, was occupied by the Netherlands, the second position - France which previously were ranked in the opposite order. Spain was ranked third, since 2008, Denmark was fourth. In the years 2005-2007, these countries occupied the fourth and third places, respectively. Latvia was ranked 5 th. In the analyzed period, this country moved up 10 places. Romania also recorded a significant improvement in competitiveness. It moved from the last place in 2005 to the 21 st place in 2012, as well as 
Portugal which moved up 3 places and was finally ranked 20th. The growth in synthetic measure was also recorded in Germany, Poland, Italy, Bulgaria and Croatia which, however, kept their places and in Hungary and Greece which moved down one position despite a growth in the value of the synthetic index (respectively to the 15th and 14th place). The total assessment demonstrates the fact that the least competitive countries included Malta, Finland, Slovenia, Cyprus, Luxembourg and Sweden, and the largest drops in the ranking of competitiveness related to Cyprus (by 5 positions) as well as Ireland (by 4 positions). Negative changes regarding the competitiveness of the food industry also related to Austria, Belgium, the Czech Republic, Malta, Slovenia Sweden and Great Britain.

\section{Discussion}

The European Union is the largest exporter of agricultural and food products in the world (Bułkowska 2011). The research of Wijnands and others 2008 demonstrates, however, that the competitiveness of the food industry of the European Union on the global market measured by the synthetic index taking into account indexes of international trade, work productivity, the share of the food industry in the total industry as well as the growth in added value is relatively low as compared to such countries as the United States and Canada and on a similar level as Australia and Brazil. Old member states still play the dominant role on the international market among Community countries. In the years 20052012 the highest competitive positions were occupied the same countries: the Netherlands, France, Spain and Denmark, only their order changed depending on the adopted time horizon. The Netherlands, France and Germany are the largest food exporters to the global market, after the United States. Brazil occupies the next place. It replaced Spain on the fourth position, and previously Canada (Bułkowska 2011). The research of Carraresi L. and Banterle (2008) indicates the fact that Germany, France and the Netherlands demonstrate the largest share in the export of food and agricultural products also on in the intra-community market. The Netherlands, France and Denmark also obtained high comparative advantages, a positive trade balance in the exchange of food products on the global market as well as a large share of inter-industry nature. The food industry in Germany does not reach revealed comparative advantages, on the other hand, which indicates a relatively small significance of this industry in the total domestic export and recorded a negative balance of foreign trade in food products. For this reason, Germany was ranked only on the 6th position in the total assessment of international competitiveness despite a large share in the global export market.

New EU member states recorded the largest improvement in competitiveness. The expansion of the Community resulted in the effect of trade creation and the development of intra-community trade, including agricultural and food products (Pawlak et al., 2010). Issues regarding changes in competitiveness of the EU food industry in the context of the Community's expansion is the subject of research, among others, by Carraresi L. and Banterle (2013) as well as Drabik and Bartova L. (2008). The conducted research suggests that a particularly high growth in the competitiveness of the food industry was recorded in Romania and Latvia. Poland had the largest share in the global export of food products among new member states. The significance of the food industry in this country is also emphasized by Antiminiani and others (2008). The authors indicate the fact that it is characterized by the largest competitive potential of this industry on the EU market among states of the new EU - similar to countries of the old EU, in particular to Germany. Poland's competitiveness is also confirmed by the scale of the surplus of commercial turnover measured with the TC index. The significance of other countries from Eastern Europe as well as Cyprus and Malta is, on the other hand, marginal. We should not expect significant changes in the level of international competitiveness of the food industry in particular EU member states in the future (maintaining the present conditions). 


\section{References}

[1] Antimiani A., Carbone A., Costantini V. and Henke R. (2012). Agri-food exports in the enlarged European Union, Agricultural Economics - Czech 58(8).

[2] Balassa, B. (1965). Trade Liberalization and Revealed Comparative Advantage. The Manchester School, 33/1965, 99-123.

[3] Bułkowska M. (2011). Handel światowymi artykułami rolno-spożywczymi w latach 2000-2009; miejsce nowych państw członkowskich UE. Zeszyty Naukowe SGGW w Warszawie - Problemy Rolnictwa Światowego vol. 11 (26).

[4] Carraresi L., Banterle A. (2013). The agri-food competitive performance in the EU countries: a fifteen years retrospective. Proceedings in Food System Dynamics, North America, available at http://centmapress.llb.unibonn.de/ojs/index.php/proceedings/article/view/314/298. Date accessed: October 19, 2013.

[5] Carraresi L., Banterle A. (2008). Measuring competitiveness in the EU market: a comparison between food industry and agriculture. paper presented at the 12th EAAE Congress, Gent, Belgium, August 27-30.

[6] Data \& Trends of the European Food and Drink Industry (2012). FoodDrinkEurope, April 2013, available at http://www.fooddrinkeurope.eu.

[7] Drabik and Bartova L. (2008), Agri-food Trade Specialisation Pattern in the New EU Member States. The XIlth Congress of the European Association of Agricultural Economists, August 26-29, 2008, Ghent, Belgium.

[8] European competitiveness report - 2003. Commission staff working document. SEC (2003) 1299 final, November 17, 2003.

[9] Fisher C., Schornberg S. (2007). Assesing the competitiveness situation of EU food and drink manufacturing inustres: an index - based approach. Agribusiness, 23 (4), 473-495.

[10] Frohberg K., Hartmann M. (1997). Comparing Measures of Competitiveness, Discussion Paper No. 2, Institute of Agricultural Development in central and Eastern Europe, Halle, Germany.

[11] Grubel H.G., Lloyd P.J. (1975). Intra-Industry Trade: the Theory and Measurement of Intra-Industry Trade in Differentiated Products, Macmillan, London, 21-23.

[12] Grubel H.G., Lloyd P.J. (1971). The Empirical Measurement of Intra-Industry Trade. The Economic Record, Vol. 47, 494-517.

[13] Hatzichronoglou, T. (1996). Globalisation and Competitiveness: Relevant Indicators, OECD Science, Technology and Industry Working Papers, 1996/05, OECD Publishing. http://dx.doi.org/10.1787/885511061376.

[14] Kim D. and Marion B. W. (1995). Domestic market structure and performance in global markets: theory and empirical evidence from U.S. food manufacturing industries. Food System Organization, Performance and Public Policies, University of Wisconsin-Madison, Department of Agricultural Economics, Report WP109, October.

[15] Martin L., Westgren R., Duren, Van E. (1991). Agribusiness Competitiveness across National Boundaries, American Journal of Agricultural Economic, 73, 1457-1464.

[16] Misala J. (2007). Międzynarodowa zdolność konkurencyjna i międzynarodowa konkurencyjność gospodarki narodowej. Podstawy teoretyczne, Politechnika Radomska, Radom.

[17] Pawlak K., Kołodziejczak M., Kołodziejczak W. (2010). Konkurencyjność sektora rolno-spożywczego nowych krajów członkowskich UE w handlu wewnątrzwspólnotowym, Zagadnienia Ekonomiki Rolnej, 126-141.

[18] Pawlak K. (2013). Międzynarodowa zdolność konkurencyjna sektora rolno-spożywczego krajów Unii Europejskiej. Uniwersytet Przyrodniczy w Poznaniu, Poznań.

[19] Pitts, E. and Lagnevik M. (1998). What determines food industry competitiveness? In W. B. Traill and E. Pitts (eds), Competitiveness in the food industry. Blackie Academic \& Professional, 1-34.

[20] Sobków Cz., Łapinska J. (2009) Problemy metodologiczne związane z pomiarem intensywności handlu wewnątrzgałęziowego. Roczniki Naukowe SERiA. Volume X, Z. 1.

[21] Wijnands J.H.M., Bremmers H.J., Van der Meulen B.M.J., Poppe K.J., (2008). An economic and legal assessment of the EU food industry's competitiveness. Agribusiness. 24, 4, 417-439.

[22] Wijnands J.H.M, Van der Meulen B.M.J., Poppe K.J., (2006). Competitveness of the European food industry. An economic and legal assessment. European Commision Enterprise, LEI, The Hague.

[23] Wziątek-Kubiak A. (2003). Konkurencyjność polskiego przemysłu. Bellona, Warsaw.

[24] http://comtrade.un.org 
Tables

Table 1. Level and changes in share of export in the global market of the food industry of EU member states in the years 2005-2012.

\begin{tabular}{|c|c|c|c|c|c|c|c|c|c|c|}
\hline \multirow{2}{*}{ No. } & \multirow{2}{*}{ Country } & \multicolumn{8}{|c|}{$\begin{array}{l}\text { Share of export in the global market of the food industry of EU member states [\%] } \\
\text { in: }\end{array}$} & \multirow{2}{*}{$\begin{array}{l}\text { Change in the } \\
\text { years 2005-2012 } \\
\text { [percentage } \\
\text { points] }\end{array}$} \\
\hline & & 2005 & 2006 & 2007 & 2008 & 2009 & 2010 & 2011 & 2012 & \\
\hline 1 & Austria & 1,17 & 1,18 & 1,18 & 1,15 & 1,10 & 1,03 & 1,03 & 1,03 & $-0,14$ \\
\hline 2 & Belgium & 4,38 & 4,29 & 4,25 & 4,17 & 4,03 & 3,68 & 3,61 & 3,62 & $-0,76$ \\
\hline 3 & Bulgaria & 0,16 & 0,15 & 0,15 & 0,22 & 0,22 & 0,24 & 0,25 & 0,27 & 0,11 \\
\hline 4 & Croatia & 0,13 & 0,16 & 0,15 & 0,13 & 0,14 & 0,12 & 0,12 & 0,13 & 0,00 \\
\hline 5 & Cyprus & 0,04 & 0,04 & 0,04 & 0,03 & 0,03 & 0,03 & 0,03 & 0,03 & $-0,01$ \\
\hline 6 & $\begin{array}{l}\text { Czech } \\
\text { Republic }\end{array}$ & 0,46 & 0,46 & 0,51 & 0,52 & 0,51 & 0,45 & 0,51 & 0,55 & 0,09 \\
\hline 7 & Denmark & 2,38 & 2,34 & 2,17 & 2,03 & 1,95 & 1,78 & 1,72 & 1,67 & $-0,71$ \\
\hline 8 & Estonia & 0,11 & 0,11 & 0,14 & 0,13 & 0,12 & 0,13 & 0,14 & 0,15 & 0,04 \\
\hline 9 & Finland & 0,20 & 0,21 & 0,23 & 0,22 & 0,18 & 0,19 & 0,20 & 0,19 & $-0,01$ \\
\hline 10 & France & 7,46 & 7,24 & 7,19 & 6,99 & 6,48 & 6,19 & 6,32 & 6,20 & $-1,26$ \\
\hline 11 & Germany & 6,70 & 6,77 & 6,69 & 6,82 & 6,82 & 6,34 & 6,48 & 6,44 & $-0,25$ \\
\hline 12 & Greece & 0,48 & 0,49 & 0,49 & 0,47 & 0,50 & 0,48 & 0,45 & 0,47 & $-0,01$ \\
\hline 13 & Hungary & 0,58 & 0,58 & 0,70 & 0,72 & 0,66 & 0,65 & 0,68 & 0,71 & 0,12 \\
\hline 14 & Ireland & 1,57 & 1,59 & 1,58 & 1,32 & 1,20 & 1,14 & 1,14 & 1,11 & $-0,46$ \\
\hline 15 & Italy & 3,91 & 3,84 & 3,88 & 3,82 & 3,77 & 3,60 & 3,51 & 3,52 & $-0,39$ \\
\hline 16 & Latvia & 0,10 & 0,11 & 0,12 & 0,14 & 0,13 & 0,15 & 0,15 & 0,21 & 0,11 \\
\hline 17 & Lithuania & 0,22 & 0,26 & 0,33 & 0,36 & 0,33 & 0,34 & 0,36 & 0,44 & 0,21 \\
\hline 18 & Luxembourg & 0,12 & 0,11 & 0,10 & 0,10 & 0,11 & 0,10 & 0,10 & 0,10 & $-0,02$ \\
\hline 19 & Malta & 0,02 & 0,03 & 0,03 & 0,03 & 0,01 & 0,02 & 0,02 & 0,02 & 0,00 \\
\hline 20 & Netherlands & 6,46 & 6,43 & 6,62 & 6,41 & 6,43 & 6,11 & 6,51 & 6,44 & $-0,02$ \\
\hline 21 & Poland & 1,35 & 1,44 & 1,55 & 1,62 & 1,59 & 1,62 & 1,69 & 1,84 & 0,50 \\
\hline 22 & Portugal & 0,44 & 0,45 & 0,49 & 0,49 & 0,50 & 0,50 & 0,50 & 0,52 & 0,08 \\
\hline 23 & Romania & 0,08 & 0,09 & 0,10 & 0,18 & 0,20 & 0,25 & 0,28 & 0,31 & 0,23 \\
\hline 24 & Slovakia & 0,22 & 0,25 & 0,26 & 0,25 & 0,26 & 0,25 & 0,28 & 0,33 & 0,10 \\
\hline 25 & Slovenia & 0,08 & 0,09 & 0,11 & 0,11 & 0,11 & 0,09 & 0,09 & 0,09 & 0,00 \\
\hline 26 & Spain & 4,27 & 4,11 & 4,06 & 3,91 & 3,97 & 3,65 & 3,58 & 3,77 & $-0,50$ \\
\hline 27 & Sweden & 0,75 & 0,78 & 0,76 & 0,76 & 0,75 & 0,78 & 0,75 & 0,77 & 0,02 \\
\hline 28 & $\begin{array}{l}\text { Great } \\
\text { Britain }\end{array}$ & 3,11 & 2,96 & 2,94 & 2,64 & 2,62 & 2,63 & 2,67 & 2,64 & $-0,47$ \\
\hline
\end{tabular}

Source: prepared by the author on the basis of UN COMTRADE - http://comtrade.un.org 
Table 2. Level and dynamics of the RCA index in the food industry in EU member states in the years 2005-2012

\begin{tabular}{|c|c|c|c|c|c|c|c|c|c|c|}
\hline \multirow{2}{*}{ No. } & \multirow{2}{*}{ Country } & \multicolumn{8}{|c|}{ Level of the RCA index in the food industry in EU member states [\%] in: } & \multirow{2}{*}{$\begin{array}{l}\text { Pace of changes in } \\
\text { the years 2005- } \\
2012 \\
{[\%]}\end{array}$} \\
\hline & & 2005 & 2006 & 2007 & 2008 & 2009 & 2010 & 2011 & 2012 & \\
\hline 1 & Austria & 1,01 & 1,04 & 1,02 & 1,05 & 1,02 & 1,05 & 1,05 & 1,03 & 2,47 \\
\hline 2 & Belgium & 1,33 & 1,38 & 1,34 & 1,37 & 1,33 & 1,32 & 1,31 & 1,29 & $-2,79$ \\
\hline 3 & Bulgaria & 1,36 & 1,19 & 1,12 & 1,51 & 1,61 & 1,75 & 1,54 & 1,60 & 17,94 \\
\hline 4 & Croatia & 1,55 & 1,58 & 1,63 & 1,45 & 1,65 & 1,55 & 1,57 & 1,66 & 7,63 \\
\hline 5 & Cyprus & 2,52 & 2,94 & 3,31 & 3,08 & 2,69 & 2,76 & 2,74 & 2,41 & $-4,24$ \\
\hline 6 & $\begin{array}{l}\text { Czech } \\
\text { Republic }\end{array}$ & 0,60 & 0,58 & 0,57 & 0,56 & 0,55 & 0,51 & 0,54 & 0,57 & $-6,26$ \\
\hline 7 & Denmark & 2,94 & 3,03 & 2,88 & 2,73 & 2,56 & 2,73 & 2,63 & 2,53 & $-13,90$ \\
\hline 8 & Estonia & 1,35 & 1,32 & 1,57 & 1,46 & 1,35 & 1,44 & 1,29 & 1,28 & $-5,00$ \\
\hline 9 & Finland & 0,32 & 0,32 & 0,35 & 0,35 & 0,35 & 0,39 & 0,44 & 0,42 & 31,35 \\
\hline 10 & France & 1,75 & 1,80 & 1,81 & 1,84 & 1,70 & 1,79 & 1,88 & 1,78 & 1,94 \\
\hline 11 & Germany & 0,70 & 0,72 & 0,68 & 0,73 & 0,74 & 0,74 & 0,75 & 0,73 & 4,36 \\
\hline 12 & Greece & 2,82 & 2,81 & 2,81 & 2,91 & 3,03 & 3,26 & 2,46 & 2,14 & $-24,03$ \\
\hline 13 & Hungary & 0,95 & 0,93 & 1,01 & 1,05 & 0,97 & 1,02 & 1,05 & 1,10 & 15,15 \\
\hline 14 & Ireland & 1,45 & 1,74 & 1,75 & 1,63 & 1,25 & 1,43 & 1,55 & 1,50 & 3,74 \\
\hline 15 & Italy & 1,06 & 1,09 & 1,05 & 1,10 & 1,13 & 1,19 & 1,16 & 1,12 & 5,34 \\
\hline 16 & Latvia & 1,84 & 2,15 & 2,06 & 2,41 & 2,29 & 2,45 & 2,16 & 2,62 & 42,20 \\
\hline 17 & Lithuania & 1,88 & 2,22 & 2,57 & 2,36 & 2,40 & 2,42 & 2,22 & 2,35 & 25,01 \\
\hline 18 & Luxembourg & 0,92 & 0,92 & 0,87 & 0,93 & 1,03 & 1,08 & 1,04 & 1,12 & 22,00 \\
\hline 19 & Malta & 1,03 & 1,09 & 1,27 & 1,39 & 0,67 & 0,82 & 0,59 & 0,66 & $-35,38$ \\
\hline 20 & Netherlands & 1,88 & 1,90 & 1,88 & 1,84 & 1,82 & 1,83 & 2,12 & 1,85 & $-1,20$ \\
\hline 21 & Poland & 1,53 & 1,56 & 1,51 & 1,47 & 1,42 & 1,53 & 1,55 & 1,64 & 7,05 \\
\hline 22 & Portugal & 1,17 & 1,24 & 1,29 & 1,38 & 1,39 & 1,52 & 1,48 & 1,41 & 20,45 \\
\hline 23 & Romania & 0,30 & 0,33 & 0,32 & 0,58 & 0,61 & 0,76 & 0,78 & 0,86 & 187,25 \\
\hline 24 & Slovakia & 0,71 & 0,70 & 0,61 & 0,55 & 0,57 & 0,57 & 0,62 & 0,65 & $-9,50 \%$ \\
\hline 25 & Slovenia & 0,48 & 0,53 & 0,55 & 0,59 & 0,60 & 0,57 & 0,56 & 0,53 & $9,47 \%$ \\
\hline 26 & Spain & 2,25 & 2,28 & 2,17 & 2,19 & 2,17 & 2,19 & 2,07 & 2,11 & $-6,44$ \\
\hline 27 & Sweden & 0,59 & 0,63 & 0,61 & 0,65 & 0,70 & 0,73 & 0,69 & 0,71 & 21,37 \\
\hline 28 & Great Britain & 0,82 & 0,79 & 0,90 & 0,90 & 0,91 & 0,96 & 0,97 & 0,87 & 6,48 \\
\hline
\end{tabular}

Source: prepared by the author on the basis of UN COMTRADE - http://comtrade.un.org 
Table 3. Level and dynamics of the Trade Coverage index in the food industry in EU member states in the years 20052012 Level of the Trade Coverage index in the food industry in EU member states [\%] in: Pace of

No. Country

$\begin{array}{llllllll}2005 & 2006 \quad 2007 \quad 2008 \quad 2009 & 2010 \quad 2011 \quad 2012 & \text { the years } \\ 2005-2012\end{array}$

[\%]

\begin{tabular}{|c|c|c|c|c|c|c|c|c|c|c|}
\hline 1 & Austria & 1,00 & 1,05 & 1,03 & 1,01 & 0,97 & 1,01 & 1,01 & 0,9931 & $-0,97$ \\
\hline 2 & Belgium & 1,17 & 1,18 & 1,15 & 1,14 & 1,17 & 1,21 & 1,17 & 1,19 & 1,72 \\
\hline 3 & Bulgaria & 1,23 & 1,02 & 0,80 & 0,93 & 0,90 & 1,10 & 1,06 & 1,14 & $-6,97$ \\
\hline 4 & Croatia & 0,57 & 0,68 & 0,62 & 0,54 & 0,63 & 0,63 & 0,60 & 0,63 & 11,14 \\
\hline 5 & Cyprus & 0,33 & 0,29 & 0,28 & 0,24 & 0,23 & 0,23 & 0,27 & 0,25 & $-23,41$ \\
\hline 6 & $\begin{array}{l}\text { Czech } \\
\text { Republic }\end{array}$ & 0,73 & 0,68 & 0,70 & 0,71 & 0,69 & 0,67 & 0,71 & 0,76 & 5,01 \\
\hline 7 & Denmark & 1,73 & 1,68 & 1,60 & 1,53 & 1,62 & 1,54 & 1,51 & 1,54 & $-11,19$ \\
\hline 8 & Estonia & 0,69 & 0,69 & 0,75 & 0,72 & 0,71 & 0,79 & 0,82 & 0,89 & 28,48 \\
\hline 9 & Finland & 0,42 & 0,44 & 0,47 & 0,44 & 0,35 & 0,39 & 0,42 & 0,39 & $-5,46$ \\
\hline 10 & France & 1,29 & 1,31 & 1,29 & 1,29 & 1,17 & 1,23 & 1,29 & 1,28 & $-0,89$ \\
\hline 11 & Germany & 0,79 & 0,81 & 0,84 & 0,88 & 0,88 & 0,88 & 0,88 & 0,91 & 15,93 \\
\hline 12 & Greece & 0,51 & 0,52 & 0,50 & 0,51 & 0,56 & 0,63 & 0,63 & 0,73 & 43,17 \\
\hline 13 & Hungary & 1,41 & 1,40 & 1,57 & 1,54 & 1,54 & 1,65 & 1,67 & 1,85 & 31,31 \\
\hline 14 & Ireland & 1,78 & 1,76 & 1,68 & 1,53 & 1,42 & 1,51 & 1,55 & 1,44 & $-18,78$ \\
\hline 15 & Italy & 0,86 & 0,86 & 0,88 & 0,92 & 0,92 & 0,94 & 0,90 & 0,95 & 10,43 \\
\hline 16 & Latvia & 0,66 & 0,65 & 0,65 & 0,73 & 0,79 & 0,89 & 0,87 & 1,14 & 72,55 \\
\hline 17 & Lithuania & 1,16 & 1,12 & 1,20 & 1,10 & 1,18 & 1,19 & 1,17 & 1,27 & 9,84 \\
\hline 18 & Luxembourg & 0,43 & 0,43 & 0,43 & 0,44 & 0,43 & 0,46 & 0,47 & 0,46 & 5,42 \\
\hline 19 & Malta & 0,33 & 0,36 & 0,36 & 0,34 & 0,17 & 0,32 & 0,29 & 0,35 & 6,23 \\
\hline 20 & Netherlands & 1,65 & 1,63 & 1,58 & 1,51 & 1,54 & 1,57 & 1,48 & 1,46 & $-11,73$ \\
\hline 21 & Poland & 1,40 & 1,41 & 1,29 & 1,19 & 1,24 & 1,26 & 1,28 & 1,41 & 0,66 \\
\hline 22 & Portugal & 0,42 & 0,45 & 0,45 & 0,48 & 0,51 & 0,52 & 0,54 & 0,59 & 38,19 \\
\hline 23 & Romania & 0,24 & 0,24 & 0,19 & 0,33 & 0,39 & 0,59 & 0,64 & 0,69 & 186,30 \\
\hline 24 & Slovakia & 0,72 & 0,76 & 0,71 & 0,61 & 0,61 & 0,62 & 0,70 & 0,77 & 7,98 \\
\hline 25 & Slovenia & 0,45 & 0,47 & 0,47 & 0,47 & 0,47 & 0,46 & 0,45 & 0,45 & $-0,46$ \\
\hline 26 & Spain & 1,09 & 1,09 & 1,04 & 1,08 & 1,20 & 1,21 & 1,19 & 1,31 & 19,33 \\
\hline 27 & Sweden & 0,56 & 0,56 & 0,54 & 0,56 & 0,55 & 0,58 & 0,57 & 0,57 & 2,24 \\
\hline 28 & Great Britain & 0,43 & 0,43 & 0,43 & 0,43 & 0,44 & 0,48 & 0,50 & 0,49 & 13,73 \\
\hline
\end{tabular}

Source: prepared by the author on the basis of UN COMTRADE - http://comtrade.un.org 
Table 4. Level and dynamics of the Grubel-Lloyd index in the food industry in EU member states in the years 2005-2012

\begin{tabular}{|c|c|c|c|c|c|c|c|c|c|c|}
\hline \multirow{2}{*}{ No. } & \multirow{2}{*}{ Country } & \multicolumn{8}{|c|}{ Level of the Grubel-Lloyd index in the food industry in EU member states [\%] in: } & \multirow{2}{*}{$\begin{array}{l}\text { Pace of changes } \\
\text { in the years 2005- } \\
2012 \\
{[\%]}\end{array}$} \\
\hline & & 2005 & 2006 & 2007 & 2008 & 2009 & 2010 & 2011 & 2012 & \\
\hline 1 & Austria & 1,00 & 0,98 & 0,99 & 0,99 & 0,99 & 1,00 & 0,99 & 1,00 & $-0,21$ \\
\hline 2 & Belgium & 0,92 & 0,92 & 0,93 & 0,94 & 0,92 & 0,91 & 0,92 & 0,91 & $-0,92$ \\
\hline 3 & Bulgaria & 0,90 & 0,99 & 0,89 & 0,96 & 0,95 & 0,95 & 0,97 & 0,93 & 4,00 \\
\hline 4 & Croatia & 0,73 & 0,81 & 0,76 & 0,70 & 0,77 & 0,77 & 0,75 & 0,78 & 6,81 \\
\hline 5 & Cyprus & 0,49 & 0,45 & 0,43 & 0,39 & 0,37 & 0,38 & 0,43 & 0,40 & $-18,70$ \\
\hline 6 & $\begin{array}{l}\text { Czech } \\
\text { Republic } \\
\end{array}$ & 0,84 & 0,81 & 0,82 & 0,83 & 0,82 & 0,80 & 0,83 & 0,87 & 2,84 \\
\hline 7 & Denmark & 0,73 & 0,75 & 0,77 & 0,79 & 0,76 & 0,79 & 0,80 & 0,79 & 7,64 \\
\hline 8 & Estonia & 0,82 & 0,82 & 0,86 & 0,83 & 0,83 & 0,88 & 0,90 & 0,94 & 15,05 \\
\hline 9 & Finland & 0,59 & 0,61 & 0,64 & 0,61 & 0,52 & 0,57 & 0,59 & 0,56 & $-3,92$ \\
\hline 10 & France & 0,87 & 0,87 & 0,87 & 0,88 & 0,92 & 0,90 & 0,87 & 0,88 & 0,50 \\
\hline 11 & Germany & 0,88 & 0,89 & 0,91 & 0,94 & 0,93 & 0,94 & 0,94 & 0,95 & 8,33 \\
\hline 12 & Greece & 0,68 & 0,69 & 0,67 & 0,68 & 0,72 & 0,77 & 0,78 & 0,84 & 24,95 \\
\hline 13 & Hungary & 0,83 & 0,83 & 0,78 & 0,79 & 0,79 & 0,75 & 0,75 & 0,70 & $-15,48$ \\
\hline 14 & Ireland & 0,72 & 0,73 & 0,75 & 0,79 & 0,83 & 0,80 & 0,78 & 0,82 & 13,66 \\
\hline 15 & Italy & 0,92 & 0,93 & 0,93 & 0,96 & 0,96 & 0,97 & 0,95 & 0,97 & 5,36 \\
\hline 16 & Latvia & 0,79 & 0,79 & 0,79 & 0,85 & 0,88 & 0,94 & 0,93 & 0,94 & 17,77 \\
\hline 17 & Lithuania & 0,93 & 0,94 & 0,91 & 0,95 & 0,92 & 0,91 & 0,92 & 0,88 & $-5,01$ \\
\hline 18 & Luxembourg & 0,60 & 0,60 & 0,60 & 0,61 & 0,61 & 0,63 & 0,64 & 0,63 & 3,72 \\
\hline 19 & Malta & 0,49 & 0,53 & 0,53 & 0,51 & 0,29 & 0,48 & 0,45 & 0,52 & 4,63 \\
\hline 20 & Netherlands & 0,75 & 0,76 & 0,77 & 0,80 & 0,79 & 0,78 & 0,81 & 0,81 & 7,89 \\
\hline 21 & Poland & 0,83 & 0,83 & 0,87 & 0,91 & 0,89 & 0,89 & 0,88 & 0,83 & $-0,39$ \\
\hline 22 & Portugal & 0,60 & 0,62 & 0,62 & 0,65 & 0,67 & 0,69 & 0,70 & 0,74 & 24,09 \\
\hline 23 & Romania & 0,39 & 0,38 & 0,32 & 0,49 & 0,57 & 0,74 & 0,78 & 0,82 & 110,31 \\
\hline 24 & Slovakia & 0,83 & 0,86 & 0,83 & 0,76 & 0,76 & 0,77 & 0,82 & 0,87 & 4,50 \\
\hline 25 & Slovenia & 0,62 & 0,64 & 0,64 & 0,64 & 0,64 & 0,63 & 0,62 & 0,62 & $-0,32$ \\
\hline 26 & Spain & 0,96 & 0,96 & 0,98 & 0,96 & 0,91 & 0,90 & 0,91 & 0,87 & $-9,17$ \\
\hline 27 & Sweden & 0,72 & 0,72 & 0,71 & 0,71 & 0,71 & 0,74 & 0,72 & 0,73 & 1,42 \\
\hline 28 & Great Britain & 0,60 & 0,60 & 0,60 & 0,60 & 0,61 & 0,65 & 0,67 & 0,66 & 9,22 \\
\hline
\end{tabular}

Source: prepared by the author on the basis of UN COMTRADE - http://comtrade.un.org 
Table 5. Level of the synthetic index as well as ranking of the competitiveness of the food industry of EU member states in the years 2005-2012

\begin{tabular}{|c|c|c|c|c|c|c|c|c|c|c|c|}
\hline \multirow{2}{*}{ No. } & \multirow{2}{*}{ Country } & \multicolumn{8}{|c|}{$\begin{array}{l}\text { Level of the synthetic index in the food industry in EU member } \\
\text { states [\%] in: }\end{array}$} & \multirow[t]{2}{*}{ Ranking 2005} & \multirow{2}{*}{ Ranking 2012} \\
\hline & & 2005 & 2006 & 2007 & 2008 & 2009 & 2010 & 2011 & 2012 & & \\
\hline 1 & Austria & 0,30 & 0,28 & 0,28 & 0,28 & 0,23 & 0,24 & 0,24 & 0,19 & 11 & 13 \\
\hline 2 & Belgium & 0,74 & 0,72 & 0,71 & 0,72 & 0,70 & 0,64 & 0,63 & 0,58 & 5 & 8 \\
\hline 3 & Bulgaria & 0,28 & 0,22 & $-0,09$ & 0,22 & 0,23 & 0,36 & 0,32 & 0,29 & 12 & 12 \\
\hline 4 & Croatia & $-0,29$ & $-0,13$ & $-0,22$ & $-0,44$ & $-0,19$ & $-0,31$ & $-0,35$ & $-0,27$ & 17 & 17 \\
\hline 5 & Cyprus & $-0,46$ & $-0,47$ & $-0,40$ & $-0,59$ & $-0,65$ & $-0,82$ & $-0,68$ & $-0,86$ & 20 & 25 \\
\hline 6 & $\begin{array}{l}\text { Czech } \\
\text { Republic }\end{array}$ & $-0,31$ & $-0,41$ & $-0,37$ & $-0,38$ & $-0,42$ & $-0,53$ & $-0,47$ & $-0,41$ & 18 & 19 \\
\hline 7 & Denmark & 1,09 & 1,05 & 0,97 & 0,94 & 0,92 & 0,86 & 0,88 & 0,81 & 3 & 4 \\
\hline 8 & Estonia & $-0,15$ & $-0,20$ & $-0,01$ & $-0,13$ & $-0,15$ & $-0,07$ & $-0,05$ & 0,02 & 16 & 16 \\
\hline 9 & Finland & $-1,02$ & $-0,98$ & $-0,89$ & $-0,99$ & $-1,16$ & $-1,16$ & $-1,14$ & $-1,24$ & 27 & 27 \\
\hline 10 & France & 1,21 & 1,18 & 1,18 & 1,19 & 1,11 & 1,10 & 1,16 & 1,08 & 1 & 2 \\
\hline 11 & Germany & 0,50 & 0,53 & 0,57 & 0,66 & 0,67 & 0,63 & 0,62 & 0,62 & 6 & 6 \\
\hline 12 & Greece & 0,08 & 0,02 & $-0,02$ & 0,02 & 0,21 & 0,30 & 0,09 & 0,13 & 14 & 15 \\
\hline 13 & Hungary & 0,17 & 0,15 & 0,22 & 0,23 & 0,21 & 0,18 & 0,19 & 0,18 & 13 & 14 \\
\hline 14 & Ireland & 0,48 & 0,56 & 0,56 & 0,49 & 0,36 & 0,36 & 0,42 & 0,34 & 7 & 11 \\
\hline 15 & Italy & 0,43 & 0,41 & 0,43 & 0,49 & 0,50 & 0,52 & 0,44 & 0,46 & 10 & 10 \\
\hline 16 & Latvia & $-0,03$ & 0,00 & $-0,03$ & 0,21 & 0,28 & 0,44 & 0,35 & 0,67 & 15 & 5 \\
\hline 17 & Lithuania & 0,48 & 0,55 & 0,65 & 0,61 & 0,63 & 0,58 & 0,57 & 0,58 & 8 & 7 \\
\hline 18 & Luxembourg & $-0,78$ & $-0,81$ & $-0,82$ & $-0,82$ & $-0,75$ & $-0,80$ & $-0,82$ & $-0,84$ & 24 & 24 \\
\hline 19 & Malta & $-0,99$ & $-0,92$ & $-0,85$ & $-0,90$ & $-1,49$ & $-1,22$ & $-1,42$ & $-1,28$ & 26 & 28 \\
\hline 20 & Netherlands & 1,16 & 1,14 & 1,16 & 1,14 & 1,18 & 1,11 & 1,28 & 1,13 & 2 & 1 \\
\hline 21 & Poland & 0,46 & 0,45 & 0,45 & 0,46 & 0,45 & 0,44 & 0,47 & 0,48 & 9 & 9 \\
\hline 22 & Portugal & $-0,68$ & $-0,64$ & $-0,60$ & $-0,55$ & $-0,44$ & $-0,47$ & $-0,45$ & $-0,41$ & 23 & 20 \\
\hline 23 & Romania & $-1,45$ & $-1,46$ & $-1,54$ & $-1,18$ & $-0,96$ & $-0,63$ & $-0,53$ & $-0,45$ & 28 & 21 \\
\hline 24 & Slovakia & $-0,32$ & $-0,28$ & $-0,36$ & $-0,60$ & $-0,56$ & $-0,62$ & $-0,50$ & $-0,39$ & 19 & 18 \\
\hline 25 & Slovenia & $-0,90$ & $-0,85$ & $-0,84$ & $-0,87$ & $-0,84$ & $-0,96$ & $-1,04$ & $-1,08$ & 25 & 26 \\
\hline 26 & Spain & 1,06 & 1,00 & 0,96 & 0,96 & 0,98 & 0,92 & 0,90 & 0,90 & 4 & 3 \\
\hline 27 & Sweden & $-0,58$ & $-0,58$ & $-0,60$ & $-0,61$ & $-0,56$ & $-0,58$ & $-0,66$ & $-0,68$ & 22 & 23 \\
\hline 28 & $\begin{array}{l}\text { Great } \\
\text { Britain }\end{array}$ & $-0,49$ & $-0,54$ & $-0,49$ & $-0,56$ & $-0,49$ & $-0,49$ & $-0,45$ & $-0,55$ & 21 & 22 \\
\hline
\end{tabular}

Source: prepared by the author on the basis of UN COMTRADE - http://comtrade.un.org 